\title{
Case Studies in the Sociology of Absence and Emergence: Anarcho-Populism in Russia and Mexico
}

\author{
Andrew R. Smolski, Javier Sethness, and Alexander Reid Ross ${ }^{1}$
}

This paper practices Sousa Santos' sociology of absences and emergences by establishing the absence of anarchism in populism studies and the presence of anarcho-populism as a concrete yet underappreciated type of populism. We conduct a comparative case study analysis of a set of historical cases, Zemlya $i$ Volya and the Partido Liberal Mexicano (PLM). We define the term "anarchopopulism," and analyze the relationship between anarchism and populism through a discursive and ideological theory of populism as a thin-centered ideology reliant on a rhetoric of the people. The results of our case studies demonstrate the existence of anarcho-populism in both Russia and Mexico, however not in all cases examined. Our findings challenge conceptualizations of populism that circumscribe populism within representative democracy and the logic of state sovereignty, highlighting the utility of anarchism in understanding a type of populism rooted in direct democracy and the sovereignty of federated communes. [Article copies available for a fee from The Transformative Studies Institute.E-mail address: journal@transformativestudies.org Website: http://www.transformativestudies.org 02022 by The Transformative Studies Institute. All rights reserved.]

KEYWORDS: Anarchism, Populism, Typology, Democracy, Mexico, Russia, Ideology, Rhetoric.

\footnotetext{
${ }^{1}$ Andrew R. Smolski, M.A. is a doctoral candidate in the Department of Sociology and Anthropology at North Carolina State University. Address correspondence to: Andrew R. Smolski, North Carolina State University, Department of Sociology and Anthropology, 10 Current Drive, Suite 334, Campus Box 8107, Raleigh, NC, USA; e-mail: arsmolsk@ncsu.edu.

Javier Sethness, MSN, FNP-BC is an Independent Scholar and Family Nurse Practitioner, jsethness@protonmail.com.

Alexander Reid Ross, PhD is an adjunct professor in the Department of Geography at Portland State University, aross@pdx.edu.
} 